\title{
Lung Carcinosarcoma
}

National Cancer Institute

\section{Source}

National Cancer Institute. Lung Carcinosarcoma. NCI Thesaurus. Code C45543.

A morphologic variant of lung sarcomatoid carcinoma composed of a mixture of nonsmall cell lung carcinoma and a sarcomatous component. 